\title{
Calvyn se doopleer
}

\author{
JJ STEENKAMP
}

\section{HISTORIESE INLEIDING}

Johannes Calvyn se optrede as hervormer word van die begin af gekenmerk deur 'n stryd na twee kante toe. Enersyds bedoel hy om die ware Christelike geloof aan te dui teenoor die dwaalleringe van die RoomsKatolieke Kerk. Aan die ander kant wil hy die hervormers vrypleit van die Wederdoperdom (Balke 1973: 39, 43).

Die verskyning van sy Institusie in 1536 is verhaas deur die optrede van die koning van Frankryk, Frans I (1515-1547). Veral na die "affaire des placards" in die nag van 17 op 18 Oktober 1534 word hervormers in Frankryk hewiger vervolg (Balke 1973: 38; O.S. III, 9, 23). Dit word vererger deur die uitspattighede van die Wederdopers in Münster wat einde Junie 1535 bloedig beëindig word (Balke 1973: 39, 43). Calvyn is haastig om met die Institusie dit duidelik te stel dat die hervormers, veral diegene in Frankryk, nie oor dieselfde kam geskeer moet word as die Wederdopers nie. In sy voorrede tot die Institusie wat hy reeds op 23 Augustus 1535 afgehandel het, appelleer hy aan Frans I om die onderskeid duidelik raak te sien (O.S. III, 10,31). Dit was noodsaaklik, want die teenstanders van die Hervorming het die situasie benut om hulle eie afdwaling van die ware kerk met die bloed van die vervolgdes te begrawe.

Die tussenposisie waarop Calvyn hom bevind, is die van die ware kerk. Met hierdie standpuntinname stel hy die RKK en die Wederdoperdom as 't ware op dieselfde vlak (Balke 1973: 41). Gevolglik was dit vir hom noodsaaklik om die leer van die ware kerk duidelik na vore te bring. Hierdie noodsaak betref ook die leer aangaande die doop.

Reeds in die eerste uitgawe van die Institusie van 1536, gee hy 'n uiteensetting van die doop wat hy, deur al die latere uitgawes daarvan gehandhaaf en uitgebou het. In die uitgawe van 1539 word die uiteensetting oor die doop uitgebrei met wat Calvyn 'n "aanhangsel" oor die kinderdoop noem. Met enkele klein wysigings het hy die uiteensetting só gehandhaaf in die finale uitgawe van 1559 (McNeil 1960: 1303, 1324).

Hierbenewens verskyn sy "Briève Instruction pour armer tous bon fideles contre les erreurs de la secte commune des Anabaptists" op 1 Junie 1544. 
Hy het hierdie traktaat geskryf op versoek van Farel, indertyd predikant te Neuchâtel. Dit was bedoel as antwoord op die sg Confessio Schlattensis waarmee doopgesindes in Neuchâtel op daardie stadium groot beroering veroorsaak het (Balke 1973: 170).

Calvyn se siening oor die doop was dus betreklik vroeg in sy loopbaan afgehandel. Soos al sy ander geskrifte, het dit wat hy gesê het oor die doop, ontstaan uit die noodsaaklikheid om die waarheid van die Woord opnuut te laat spreek in 'n situasie waarin die leer van die ware kerk verduister en aangeval is.

\section{LEERSTELLIGE AGTERGRONDE}

Calvyn se leer oor die doop moet hoofsaaklik gesien word teen die agtergrond van sy beskouings oor:

1. Die gelykheid (similitudo) van Ou en Nuwe Testament.

2. Die uitverkiesing.

3. Die sakramente.

\subsection{Die gelykheid (similitudo) van die OT en NT}

Dit is opmerklik dat Calvyn die gelykheid van OT en NT in die tweede boek van sy Institusie behandel (O.S. III, 403: Inst. II, 10). Hierdie posisie plaas die gelykheid van OT en NT onmiddellik in 'n soteriologiese eerder as 'n hermeneutiese konteks (Baker 1980: 196). Calvyn wil aantoon dat kennis aangaande God, die Verlosser in Christus, in beide Testamente aangetref word. Hierdie kennis is eers aan die vadere onder die Wet openbaar en later aan ons deur die evangelie (O.S. III, 228: Inst. II, 1).

Calvyn beskou die evangelie in tweërlei sin. Eerstens aanvaar hy dit in die duidelike openbaring van die misterie van Christus (clara mysterii Christi manifestatione). Verder erken hy ook per analogia fidei al die beloftes van die vrye vergewing van sondes, wat algemeen in die wet voorkom, waardeur God die mens met Homself versoen, as dele daarvan (O.S. III, Inst. II, 9,2). In hierdie opsig waak Calvyn daarteen, in stryd met Servet, om Christus bloot as onderdeel van ' $n$ voortgaande openbaring te beskou (O.S. III, 400: Inst. II, 9, 3). Die openbaring in die OT geskied tot en met Johannes die Doper wat as laaste persoon heenwys na die volle openbaring in Christus (O.S. III, 402: Inst. II, 9, 5). Met Christus vind daar ' $n$ definitiewe breuk plaas - 'n beëindiging van 
sketsmatige openbaring en 'n begin van die nuwe volmaakte in Christus (O.S. III, 401: Inst. II, 9, 3. Vgl. ook O.S. III, 428: Inst. II, 11,5).

Die gelykheid van die twee Testamente bestaan grootliks in die feit dat die beloftes van God in die O.T. dieselfde is as die in die evangelie. In albei Testamente het die beloftes eskatologiese betekenis. Die beloftes van die O.T. hou nie met Christus op nie. Net so min ontvang die gelowige in Christus op hierdie aarde reeds die voordele daarvan, al het Christus niks met betrekking tot die verlossing ongedaan gelaat nie. In die wagtydperk beveel die Heilige Gees die gelowige om op die beloftes te vertrou (O.S. III, 400-401: Inst. II, 9,3).

Calvyn wys egter daarop dat daar gelet moet word op die verskil in die aard van die beloftes; die evangelie wys met die vinger aan wat die wet in skadubeelde aangedui het (Evangelium digito monstrat quod lex sub typis adumbravit) (O.S. III, 401: Inst. II, 9,3).

Wanneer Calvyn die gelykheid van die twee toestande aandui, gee hy 'n uiteensetting van sy verbondsleer (McNeill 1960: 428). 'n Sleutel hiervoor is te vinde in wat hy in sy Institusie II, 10,1 skryf:

"Uit die voorgaande is dit reeds duidelik, dat alle mense wat God van die begin van die wêreld af tot sy volk aangeneem het, aan Hom verbind is, deur dieselfde wet en deur die band van dieselfde leer wat onder ons van krag is" (O.S. III, 403: Inst. II, 10,1. Skrywer se vertaling).

Hieruit word ' $n$ besondere verbintenis duidelik van adopsie, verbond, wet en evangelie. Dit bestaan in so ' $n$ mate dat die verbond gelykwaardig is aan God se adopsie van sy uitverkorenes deur die bemiddeling van Christus. Calvyn wys herhaaldelik op die verbond van adopsie, terwyl hy vrye genade beklemtoon (Baker 1980: 194).

Sy basiese argument is die eenheid van die geloof van die mense van die $\mathrm{Ou}$ en die Nuwe Testament. Inderdaad is sy beskouing oor die eenheid van die verbond, 'n bevestiging van die eenheid van die Testament (Baker 1980: 195). Hy sê:

"Die verbond met al die vadere verskil in wese en saak self so min van dié met ons, dat dit kortom een en dieselfde is: dit verskil slegs ten opsigte van die bediening" (O.S. III, 404: Inst. II, 10,2. Skrywer se vertaling).

Calvyn baseer hierdie beskouing op drie hoofpunte. Eerstens, stel hy, dat dit nie vleeslik voorspoed en rykdom was wat vir die Jode as doel gestel is waarna hulle moes streef nie, maar eerder dat hulle aangeneem is in die hoop op onsterflikheid en dat die waaragtigheid van hierdie aanneming vir hulle bevestig is deur Goddelike openbarings, deur die wet en deur die profete. Tweedens was die verbond, 
waardeur hulle met God verbind is, nie gegrondves op enige verdienste van hulle eie nie, maar alleen op die barmhartigheid van God wat hulle geroep het. Derdens het hulle Christus as Middelaar gehad en geken deur wie hulle met God verbind was en deur wie hulle ook in sy beloftes sou deel (O.S. III, 404: Inst. II, 10,2).

Sy eerste en derde standpunte bewys Calvyn hoofsaaklik op twee maniere, te wete eerstens vanuit die Nuwe Testament en tweedens deur logiese afleidings uit die OT Sy tweede standpunt word uiteengesit as hy die doop behandel.

Met betrekking tot die NT verwys hy na verskeie Skrifgedeeltes wat deur die skrywers gestel is, waardeur aangetoon word dat God die Vader sy seun Jesus Christus deur diens van die wet en profete beloof het, byvoorbeeld Romeine 1: 2-3. Hy konkludeer dat diegene aan wie die beloftes gemaak is, sekerlik nie bloot vleeslike plesier sou soek nie, maar indien die beloftes van die evangelie in die wet vervat is, die OT spesifiek besig was met die toekomstige lewe. Met verwysing na Lukas 1: $54-55,72-73$, stel hy byvoorbeeld dat die OT altyd sy bedoeling in Christus en die ewige lewe gehad het (O.S. III, 404-408: Inst. III, 10, 3-6).

Met betrekking tot die logiese afleidings uit die OT verwys Calvyn na God. Die vadere, Adam, Abel, Noag, Abraham en andere het deur die verligting van God se Woord aan God self vasgehou. Daarom sê hy, het hulle ingegaan in God se onsterflike koninkryk, want hulle deelname aan God was waaragtig, iets wat nie moontlik is sonder die skat van die ewige lewe nie (Erat enim solida Dei participatio, quae extra vitae aeternae bonum esse non potest) (O.S. III, 408: Inst. II, 10,7). Op dieselfde manier wys Calvyn talle bewysplase uit die OT aan waarmee hy aantoon dat die OT-vadere gehoop het op vervulling van God se beloftes in die toekomstige lewe. 'n Sprekende voorbeeld van sy redenasie is sy verwysing na Psalm 33:12: "Welgeluksalig is die nasie wie se God die Here is, die volk wat Hy vir Hom as erfdeel uitgekies het". Calvyn besluit dat dit nie so is ter wille van aardse geluk nie, maar omdat Hy hulle verlos van die dood. Hy bewaar vir ewig diegene wat Hy as sy volk gekies het en hou hulle in sy ewigdurende genade (O.S. III, 408-421: Inst. II, 10, 7-22).

Calvyn verwys in hierdie bewysplase kennelik na die wese van God. In Hom vind die vadere die bevestiging van hulle geloof, wat daarom nie op die tydelike lewe gerig kan wees nie, maar op die ewige. Die vadere kon in hulle eie lewens nie die vervulling van God se beloftes vind nie, want dit was maar ellendig. Nogtans het hulle vertrou op die 
beloftes wat op niks anders as die toekomstige lewe kon dui nie (O.S. III, 417: Inst. II, 10, 17).

Dit is opmerklik dat Calvyn in hierdie behandeling nie baie aandag daaraan gee om aan te toon dat die vadere Christus as pand van die verbond gehad het en op Hom al hulle vertroue aangaande die seën gestel het nie. Hy doen dit, omdat dit nie 'n strydpunt was nie en omdat dit in elk geval baie duidelik was (O.S. III, 421: Inst. II, 10,23). Verder het hy hierdie saak op verskeie ander plekke in sy Institusie aangetoon. Hy volstaan deur die beginsel te stel, dat die OT of verbond wat die Here met die Israeliete gemaak het, nie beperk was tot aardse dinge nie, maar ' $n$ belofte van geestelike en ewige lewe ingehou het. In hierdie verband verwys hy byvoorbeeld na Matteus 8: 11 waar gelowiges van oor die hele wêreld saam met Abraham, Isak en Jakob sal aansit in die koninkryk van die hemele (O.S. III, 421-422: Inst. II, 10, 23).

Die vyf verskille wat Calvyn aantoon tussen die OT en die NT bevestig eintlik slegs die basiese eenheid van die twee Testamente. Hy stel dat dit dinge is wat eerder tot die bedieningswyse behoort as tot die substansie (van die verbond of testament). Geeneen van die verskille verhinder dat die beloftes van die OT en die NT dieselfde bly, of ook dat die fondament van hulle beloftes dieselfde bly, naamlik Christus (O.S. III, 423: Inst. II, 11,1).

Vir ons doel sal dit voldoende wees om te wys op die volgende: Die verskille wat Calvyn noem tussen die OT en die NT bring baie pertinent na vore dat sy verbondsleer nie dui op 'n voorwaardelike verbond, dit wil sê 'n verbond tussen twee partye, naamlik God en mens nie (Baker 1980: 195-198). Hoewel hy in hierdie hoofstukke van sy Institusie die twee terme foedus en testamentum afwisselend gebruik (McNeill 1960: 453), is dit duidelik dat hy met verbond inderdaad testament bedoel, dit wil sê ' $n$ eensydige verbintenis van God aan sy uitverkorenes met al die beloftes wat in die verbintenis vervat is. Die verantwoordelikheid van die gelowige in hierdie verband vind alleen uiting in die tertius usus legis (ethicus), maar geensins in 'n voorwaardelike betekenis nie (Baker 1980: 195).

In die lig van die voorafgaande dien Calvyn se verbondsleer, sy idee van 'n testament, dus die doel om God se genade in die twee bedienings, die oue en die nuwe, te verbind. Dit is die raamwerk waarbinne God met sy uitverkorenes deur alle eeue gehandel het (Baker 1980: 197).

Hierdie interpretasie plaas die hele verbondsleer teen die agtergrond 
van die volgende leerstuk wat belangrik is vir sy doopleer, naamlik sy uitverkiesingsleer (Baker 1980: 197-198. Vgl ook Dankbaar 1941: 126-127).

\subsection{Die uitverkiesingsleer}

In die 1539-uitgawe van sy Institusie stel Calvyn sy leerstukke oor die verbond en die uitverkiesing naas mekaar, sonder 'n besondere verbintenis van die twee. Na die episode met Hieronymus Bolsec in 1551 en sy daaropvolgende Consensus pastorum Genevensis Ecclesiae de acterna Dei praedestinatione, word die leer van die uitverkiesing vir Calvyn belangriker as dié van die verbond (Baker 1980: 196-197). Weer eens 'n antwoord op 'n probleemsituasie.

Hierdie belangrikheid van die uitverkiesingsleer word dermate uitgebou, dat die verbondsleer uiteindelik in die Institusie van 1559 volledig binne die trefwydte van die uitverkiesingsleer vasgelê word (O.S. IV 374: Inst. III, 21,5).

Wat die uitverkiesing (praedestinatio) self betref, gee Calvyn die volgende kort definisie:

"Ons noem uitverkiesing die ewige besluit van God wat Hy by Homself vasgestel het, wat Hy wou hê dat van elke mens sou word. Want almal word nie met gelykstaande bestemming (conditio) geskape nie, maar vir sommige word die ewige lewe, vir ander die ewige verdoemenis voorverordineer" (O.S. IV, 374: Inst. III, 21,5. Skrywer se vertaling).

Uit hierdie definisie blyk duidelik dat die verbond logies en teologies 'n opvolgende posisie ten opsigte van die uitverkiesing inneem (Baker 1980: 197). Afgesien hiervan, bevestig Calvyn dit self in sy Inst. III, 21,5.

Dit is vir ons doel voldoende om ten opsigte van die uitverkiesingsleer op die volgende aspekte te wys:

Eerstens toon Calvyn daarmee aan dat God volkome vry is om sy genade te skenk aan wie hy wil, sonder enige verdienste van die mens se kant (O.S. IV, 375, 377: Inst. III, 21, 5 en 6). Hierdie genade is onweerstaanbaar (Wendel 1968: 241). Verder is die uitverkiesing gegrond in Christus self (Wendel 1968: 241). God wil diegene as sy kinders aanneem wat hy as lede van Christus erken (Wendel 1968: 243). In Christus word die mens uitverkies en tot erfgenaam van God gemaak (Wendel 1968: 242). Die uitverkiesing word sigbaar in die roeping tot en regverdiging deur Christus. Die geloof, bevestig deur die testimonium Spriritus sancti internum maak die roeping en regverdiging kenbaar (O.S. IV, 377: Inst. III, 21,7). 
Op die vraag na die sekerheid met betrekking tot die uitverkiesing, vind Calvyn die antwoord in die feit dat die uitverkiesing in Christus gegrondves is. Heilssekerheid word aangedui deur die unio cum Christo deur die geloof (Wendel 1968: 242). Hierop volg die vraag van die syllogismus practicus as kenteken vir die gelowige om seker te wees van die uitverkiesing. Calvyn waarsku teen die syllogismus practicus want daardeur word die blik van God afgewend en op die mens gerig. Sodoende word die heilssekerheid nie bevorder nie, maar in gevaar gestel (Niesel 1957: 182).

Calvyn verwys die gelowige vir sy heilssekerheid na die Woord van God en die aanhangsels van die Woord wat die beloftes verseël. Hierdie aanhangsels is nie die syllogismus practicus nie, maar die sakramente (Niesel 1957: 181).

\subsection{Die sakramente}

Calvyn tel die sakramente onder die uiterlike hulpmiddele waarmee God ons in die gemeenskap van Christus uitnooi en ook daarin bewaar (O.S. V, 1: Inst. IV, 1). Trouens Woord en sakrament, reg verstaan en bedien, vorm tesame elk op eie manier, die konstitutiewe faktore van die ware kerk ${ }^{1}$.

Van die sakramente gee Calvyn die volgende definisie:

"Dit lyk vir my dat 'n eenvoudige en kenmerkende definisie sou wees om te sê dat dit 'n uiterlike teken is waarmee die Here die beloftes van sy goedgunstigheid jeens ons aan ons gewetens verseël om die swakheid van ons geloof te versterk, en waarmee ons wederkerig ons vroomheid jeens Hom, sowel voor Hom en die engele, as by die mense betuig".

Of ook korter gestel:

"... dat 'n mens dit 'n getuienis van God se genade jeens ons noem, bevestig deur 'n uiterlike teken, met wederkerige betuiging van ons vroomheid jeens Hom" (O.S. V, 259: Inst. IV, 14, 1. Skrywer se vertaling).

Calvyn sê verder dat 'n sakrament nooit sonder 'n voorafgaande belofte is nie, maar eerder as ' $n$ soort aanhangsel wat daaraan toegevoeg is met die bedoeling om die belofte te bevestig en te verseël en dit meer sigbaar vir ons te maak (O.S. V, 260: Inst. IV, 14, 3). Sakramente is oefeninge om vir ons die trou van God se Woord sekerder te maak, vleeslik aangepas by ons, om ons na die mate van ons traagheid te onderrig (O.S. V, 263: Inst. IV, 14, 6). 
Teenoor die spiritualiste (McNeill 1960: 1283) stel Calvyn 'n drieërlei werkwyse van God. Eerstens leer Hy deur die Woord, tweedens bevestig Hy die Woord met die sakramente en derdens verlig Hy ons verstand en open Hy ons hart deur die Heilige Gees vir Woord en sakrament (O.S. V, 266: Inst. IV, 14, 8).

Die Heilige Gees is absoluut nodig vir die effektiwiteit van die sakrament. Sonder die Heilige Gees is die sakrament leeg en ydel (O.S. V, 266: Inst. IV, 14, 9).

Hy stel verder dat die sakramente nie magies werksaam is nie. Hulle bied niks meer as wat die Woord sê nie. Hieruit volg dat die versekering van die heil nie afhanklik is van subjektiewe deelname aan die sakramente nie. Die rede hiervoor is dat die regverdiging in Christus geleë is, dat dit deur die prediking tot die gelowige kom en dat dit standhou, selfs sonder deelname aan die sakramente (O.S. V, 271: Inst. IV, 14, 14). Christus is die wese van die sakramente, hulle is in Hom gevestig en beloof niks sonder Hom nie (O.S. V, 273: Inst. IV, 14, 16).

Vervolgens moet dit duidelik wees dat die sakramente dieselfde bediening as die Woord het, naamlik om Christus aan te bied en in Hom al die hemelse rykdomme. Hulle het egter geen waarde as hulle nie in geloof ontvang word nie (O.S. V, 274: Inst. IV, 14, 17). God is self die waarborg en steun van sy instellings deur die werking van die Heilige Gees. Daaruit volg dat Hy werklik dit skenk wat Hy met sy tekens beloof en uitbeeld (O.S. V, 275: Inst. IV, 14, 17).

Reeds in die OT het God sakramente aan sy volk gegee. Die sakramente van die OT en die NT verskil na gelang van die bedeling van die tyd waarin God Hom openbaar het. So was tekens soos die besnydenis sakramente vir die Jode tot met die koms van Christus. Met die koms van Christus is hierdie sakramente herroep en is die twee sakramente, doop en nagmaal ingestel (O.S. V, 278: Inst. IV, 14, 20).

Die sakramente in die OT het egter op dieselfde doel gedui as dié in die NT, naamlik om mense na Christus te rig en te lei. Dit is seëls om God se beloftes te verseël. En geen belofte is ooit gegee behalwe in Christus nie (2 Kor 1: 20). Gevolglik moet alle sakramente Christus vertoon as hulle ons aangaande enige belofte van God moet onderrig (O.S. V, 278: Inst. IV, 14, 20).

Wat die besnydenis spesifiek betref, stel Calvyn dat dit vir die Jode eerstens 'n teken was dat alles wat uit menslike saad voortgekom het, verdorwe is en besnoei moet word. Verder was dit vir hulle 'n bewys en herinneringsteken van die belofte aan Abraham oor die geseënde saad in wie al die nasies van die wêreld geseën sou word (Gen 22: 18). 
Met verwysing na Galasiërs 3: 16 sê Calvyn dat Christus dié saad was in wie die Jode gehoop het om dit te herwin wat hulle in Adam verloor het. Dienooreenkomstig was die besnydenis vir die Jode wat dit vir Abraham was, naamlik 'n seël wat bewys dat God hom regverdig verklaar het omdat hy geglo het. Vir die Jode is dit dus ook 'n seël waarmee hulle verseker is dat die geloof, waarmee hulle op die saad gewag het, vir hulle deur God tot regverdigheid gereken word (O.S. V, 279: Inst. IV, 14, 21).

Wat die Christelike sakramente betref, stel Calvyn dat hulle Christus meer volledig aandui, en dit in dieselfde mate waarin Christus vollediger aan die mens geopenbaar is, vandat die Vader hom waarlik geopenbaar het soos $\mathrm{Hy}$ belowe het. Die doop bevestig aan ons in die teken van die water dat ons gereinig en gewas is, die nagmaal dat ons verlos is. Ons word daarvan verseker deur die Heilige Gees (O.S. V, 279-280: Inst. IV, 14, 22).

Die doop gee nie meer as die besnydenis nie, naamlik 'n seël van die regverdiging van die geloof. Wat ons in ons sakramente kry, het die Jode in hulle s'n gekry, naamlik Christus. Dit was seëls van God se goedgunstigheid jeens hulle wat gewys het op die ewige verlossing (O.S. V, 281: Inst. IV, 14, 23). Weliswaar word die OT-seremonies as skadubeeld aangedui, nie omdat hulle geen realiteit gehad het nie, maar omdat hulle so te sê gesuspendeer was tot met die koms van Christus. Dit was so, omdat alle tekens voorafskaduwing van Christus was totdat hy vleeslik geopenbaar is (O.S. V, 282: Inst. IV, 14, 25).

Calvyn som dit op in drie punte. Eerstens is alle tekens van die OT waardeloos as dit nie na Christus heengewys het nie. Tweedens het hulle op so 'n manier op Christus gewys, dat hulle met sy koms verval het.

Derdens is hulle herroep met sy koms omdat in Christus die volle openbaring na vore gekom het. Nes skaduwees verdwyn in die helder lig van die son, moes hulle ook met die koms van Christus verdwyn (O.S. V, 283: Inst. IV, 14, 25).

\subsection{Opsommende besluit}

Calvyn se leer aangaande die gelykheid van die OT en die NT, die uitverkiesing en die sakramente kan soos volg saamgevat word: God het voor die skepping reeds by Homself besluit om vir sommige mense die ewige lewe te beskik en vir andere die ewige verdoemenis. Diegene wat uitverkies word, word in Jesus Christus uitverkies wat as tweede 
persoon van die Drie-eenheid by sy preëksistente besluit teenwoordig is. Van die begin van die skepping af het God Homself aan die mensdom openbaar, terwyl $\mathrm{Hy}$ aan sy uitverkorenes beloof het, dat $\mathrm{Hy}$ hulle sal verlos tot die ewige lewe. Die openbaring van God het in die OT baie keer en op baie maniere plaasgevind. In die NT het $\mathrm{Hy}$ Homself volmaak openbaar in die vleesgeworde, gekruisigde en opgestane Heer, Jesus Christus.

God het deur middel van sy verbond 'n raamwerk geskep waarmee Hy met sy uitverkorenes handel. Dit is een verbond in OT en NT, 'n testament wat God aan sy uitverkorenes gee om daarmee sy genade aan hulle te betoon.

Van die oomblik af dat God Abraham en sy nageslag afgesonder het om binne die verbond te leef, bestaan die kerk, die eiendom van die Here (Torrance 1960: 95).

Om sy verbond met al die beloftes wat daarin vervat is, vir sy kerk te bevestig, het God aan die kerk sy sakramente gegee. Die sakramente is bedoel om die swak geloof van die gelowiges te versterk. Hulle geld as uiterlike seëls en tekens waarmee die beloftes bevestig word.

Alle sakramente vestig in Jesus Christus. Die sakramente van die OT wys vorentoe na Christus. Daarom verval hulle met sy koms. Die sakramente van die NT wys terug op Christus en vorm saam met die Woord die konstitutiewe faktore van die kerk. Hulle moet, solank dit God behaag om die kerk in stand te hou, deur die kerk onderhou word, want hulle verseker die gelowiges, soos die sakramente van die OT, van die ewige lewe aan die einde van die tyd.

Die sakramente is vir die kerk, dus vir die gelowiges bedoel. Daarom kan hulle slegs in geloof ontvang word. Die geloof, asook die bevestiging daarvan, ontstaan en bestaan deur die testimonium Spiritus sancti internum.

Met hierdie beskouings oor uitverkiesing, verbond en sakramente bevestig Calvyn die sola gratia van die Hervorming.

\section{DIE DOOP}

Calvyn gee aan die begin van die hoofstuk oor die doop (Inst. IV, 15) die volgende omskrywing:

"Die doop is ' $n$ teken van inwyding (initiatio = deelname?) waardeur ons in die gemeenskap van die kerk aangeneem word, opdat ons, in Christus ingeplant (insiti), onder die kinders van God gereken word. En dit is aan ons deur God met die doel gegee (waarvan ek geleer het 
dat dit gemeenbesit van alle sakramente is) om in die eerste plek te dien tot 'n getuienis van ons geloof by Hom en vervolgens om tot belydenis by die mense te dien".

Wat die tweede deel van die omskrywing betref, stel Calvyn eerstens dat die doop ons geloof op drieërlei wyse dien. Eerstens stel hy teenoor Zwingli dat die doop ' $n$ teken van sondevergiffenis is (McNeill 1960: 1304). Hierdie sondevergiffenis geskied binne die raamwerk van die verbond en is dus slegs effektief vir diegene wat lede van Christus en van sy kerk is (Dankbaar 1941: 102). Dit is die teken en bewys van die afwassing van ons sondes (O.S. V, 285: Inst. IV, 15, 1). Daarby moet egter nie bloot na die water gekyk word, as sou die afwassing deur die teken geskied nie, maar wel op die beloftes wat die teken vergesel. Die doop beloof ons inderdaad geen ander reiniging as deur die besprenkeling met die bloed van Christus nie, wat deur die water afgebeeld word vanweë die gelyke vermoë om te reinig en af te was (O.S. V, 286: Inst. IV, 15, 2). Hiermee word tegelykertyd die teenwoordigheid van Christus by die sakrament aangedui (Dankbaar 1941: 102).

Met sonde bedoel Calvyn in hierdie verband die erfsonde. Daarmee stel hy sy leer tegelykertyd teenoor sowel die vroeëre gebruik in die kerk om die doop tot die laaste oomblik in 'n mens se lewe uit te stel (McNeill 1960: 1305), as die dwaling van die RKK dat die doop ex opere operato te verstaan is en dat sondes na die doop deur allerlei satisfactiones genihileer moet word (Dankbaar 1941: 102). Sou 'n mens dus in sonde val, behoort hy sy doop in herinnering te roep om altyd seker te wees van die vergewing van sondes. Die doop bly dus geldig vir ' $n$ mens se hele lewe. Calvyn vind grond vir hierdie standpunt, nie in die doop nie, maar in die reinheid van Christus (O.S. V, 287: Inst. IV, 15, 3). Die tweede voordeel wat die doop vir ons geloof meebring, is dat dit aan ons ons afsterwing in Christus en ons nuwe lewe in Hom aantoon, dit wil sê die wedergeboorte. Calvyn grond hierdie standpunt op Romeine 6: 3-4vv (O.S. V, 288-289: Inst. IV, 15, 5). Verder stel hy dat die wedergeboorte deur die Heilige Gees bewerkstellig word, wat steeds met die bediening van die doop gepaard gaan. Daarmee saam, egter, geld ook dat niemand die wedergeboorte ontvang sonder om 'n lidmaat van Jesus Christus te wees nie (Dankbaar 1941: 103). Dit beteken dus dat die gelowige nie bloot in ' $n$ imitatio Christi moet verval betreffende die mortificatio en die regeneratio nie, maar dat die gelowige seker kan wees van 'n werklike deelname aan die sterwe en die opstanding van Christus (Wendel 1968: 283; O.S. V, 288: Inst. IV, 15, 5). Dit hou vir die gelowige twee sake in: Eerstens die sekerheid van die 
genade en tweedens die verpligting tot die vita christiana (Dankbaar 1941: 104). Omdat die voleinding hiervan egter eskatologies gesien moet word, moet die kerk daagliks tot bekering oproep (Dankbaar 1941: 105).

Dankbaar konkludeer:

"... dat de wedergeboorte door Calvijn tegelijk beskouwd wordt als een gave des Heiligen Geestes door den doop, en evenseer als een plicht onzerzijds, die het rechte gebruik van den Doop medebrengt" (Dankbaar 1941: 105).

Die derde nut wat Calvyn in die doop vir ons geloof vind, is die sekere getuienis, dat ons nie alleen in die dood en die lewe van Christus ingeplant is nie, maar ook so met Christus self verenig is, dat ons deelgenote is van al sy seëninge (O.S. V, 289: Inst. IV, 15, 6). Wat Calvyn hier in 'n kort paragraaf stel, is eintlik wat hy reeds in die hele derde boek van sy Institusie behandel het, naamlik die Christusgemeenskap (unio cum Christo) (Torrance 1960: 95). Daarna is reeds verwys in die gedeelte oor die uitverkiesing. Calvyn se bedoeling hiermee is om duidelik te stel dat daar eerstens geen sprake kan wees van die gawes van Christus buite Christus om nie (Dankbaar 1941: 107). Tweedens stel hy hiermee duidelik dat die sakramente, en in hierdie geval die doop, alleen hulle plek in die kerk het (Torrance 1960: 95): Ten slotte gee hy hiermee 'n trinitariese verbintenis aan die doop. Hy stel:

"Daarom verkry ons en onderskei ons in 'n sekere sin duidelik in die Vader die oorsaak (causa), in die Seun die materia (materia), en in die Gees die uitvoering (effectus) van sowel ons reiniging (purgatio) as ons wedergeboorte (regeneratio)" (O.S. V, 289: Inst. IV, 15, 6. Skrywer se vertaling. Vgl ook Torrance 1960: 111-117).

$\mathrm{Na}$ hierdie uiteensetting onderbreek Calvyn sy gedagtegang om sowel teen die Wederdopers as die RKK te polemiseer (Wendel 1968: 284). Wat die Wederdopers betref, stel hy dat die doop van Johannes die Doper dieselfde was as die doop van die apostels. Hy verwys na die inhoud van beide doop as 'n doop tot boetedoening, tot vergewing van sonde en in die Naam van Christus. Hy grond sy stelling daarop dat Johannes gedoop het met verwysing na Christus as die Lam van God deur wie die sondes van die wêreld weggeneem sou word (Joh 1: 29). Die verskil was slegs daarin geleë dat Johannes gedoop het in Hom wat sou kom en die apostels in Hom wat Homself reeds openbaar het (Luk 3: 16 en Han 19: 4) (O.S. V, 289-290: Inst. IV, 15, 7).

Met betrekking tot Lukas 3: 16 wys hy daarop dat Johannes nie die 
een doop van die ander wou onderskei nie, maar eerder gewys het op die verskil tussen homself en Christus (O.S. V, 291: Inst. IV, 15, 8). Hierdie redenasie is in lyn met wat Calvyn geleer het oor die gelykheid van die OT en die NT Dit gaan om die gelykheid van ons geloof met die van die vadere; iets wat die Wederdopers bestry het (Wendel 1968: 284). Die polemiek teen Rome gaan oor die erfsonde en omdat dit reeds vermeld is, word volstaan met die opmerking van Wendel:

"Die Taufe versetzt uns nicht wieder in den Zustand der Unschuld Adams sondern überzeugt uns, dass Gott uns unsre Schuld und die normalerweise daraus folgende Strafe erlassen hat und er uns für gerecht hält, indem er uns Christi Gerechtigkeit zurechnet. Die Lehre von der Taufe entspricht also in ihrem logischen Aufbau ganz der Rechtfertigungslehre" (Wendel 1968: 285).

Nadat Calvyn op hierdie wyse aangedui het wat die doop vir ons geloof meebring, gaan hy daartoe oor om die tweede deel van die sakrament uiteen te sit, naamlik dat dit dien as teken van ons belydenis by die mense. Hy stel dit soos volg:

"Dit is die kenteken waardeur ons openlik bely dat ons by God se volk gereken wil word, waardeur ons betuig dat ons ooreenstem tot die verering (cultus) van die enige God, tot die een godsdiens saam met alle Christene, waardeur ons ten slotte ons geloof in die openbaar bevestig" (O.S. v, 294: Inst. IV, 15, 13. Skrywer se vertaling).

In dieselfde sin vervolg Calvyn dat die doel van hierdie belydenis is om God met hart, mond en liggaam te loof. Deur die lof van God met alles wat ons is te dien, word ander ook in dieselfde ywer aangespoor.

Met hierdie doksologiese betekenis van die belydeniskarakter van die doop, sny Calvyn alle moontlikheid af tot subjektiewe deelname aan die doop wat op die verdienstelikheid van die mens dui. Hy doen dit spesifiek met die doel om die Wederdopers se belangrikste stellings te weerlê (Wendel 1968: 285).

In hierdie verband wys Calvyn daarop dat daar onderskei moet word tussen die teken en die betekende saak. Die teken het nie opsigself 'n eie waarde wat losstaan van die beloftes wat God daaraan verbind nie (O.S. V, 295: Inst. IV, 15, 14). Die doop, as teken van ons belydenis, behoort dus gebruik te word as getuienis van ons vertroue in die genade van God (O.S. V 296: Inst. IV, 15, 15).

Calvyn weerlê die donatistiese argument van die Wederdopers, dat diegene wat nog in die RKK gedoop is, se doop nie geldig is nie, omdat hulle gedoop is deur goddelose mense en afgodedienaars van die RKK en daarom weer gedoop moet word. Hy stel dat die doop nie afhanklik 
is van die waardigheid van die bedienaar nie, omdat daar nie gedoop is in die naam van enige mens nie, maar in die Naam van die Vader, die Seun en die Heilige Gees (O.S. V, 296-297: Inst. IV, 15, 16).

Die Wederdopers het verder geargumenteer dat die doop van sulkes soos Calvyn ongeldig was, omdat dit nie in die regte geloof ontvang is nie. Calvyn antwoord hierop dat dit wel so is dat hulle, synde blind en ongelowig, vir 'n lang tyd nie die belofte kon begryp wat in die doop aangebied is nie, maar dat die belofte, van God afkomstig, steeds vas en geloofwaardig gebly het. Nou egter, begin hulle deur God se genade boete doen. Daarom moet hulle die belofte, wat steeds vasstaan, in geloof aangryp. Calvyn wys in hierdie verband daarop, dat God die Jode, wat afgedwaal het, tot boetedoening opgeroep het, ' $n$ bekering van die hart. Hy het aan hulle geen tweede besnydenis opgelê nie. Herdoop is dus nie moontlik nie (O.S. V, 297-298: Inst. IV, 15, 17).

Met betrekking tot Hand 19: 2-5, ontken Calvyn dat Paulus die dissipels van Johannes herdoop het. Hy meen dat daarmee bloot bedoel is, dat die dissipels die Heilige Gees deur Paulus se handoplegging ontvang het (Hand 19: 6vv). Hy bewys sy siening deur daarop te wys dat dit 'n gebruiklike vertelvorm onder Hebreërs was om eers 'n samevatting van ' $n$ saak te gee en daarna dit meer volledig te verduidelik (O.S. V, 299: Inst. IV, 15, 18).

In die vervolg hiervan wys Calvyn allerlei seremoniële bykomstighede soos beoefen in die RKK af, asook die sg. nooddoop en die doop deur vroue (O.S. V, 299-302: Inst. IV, 15, 19-21).

Calvyn behandel die eerste deel van sy omskrywing van die doop, dit is die deel wat handel oor die inlywing in die kerk, nie afsonderlik in die hoofstuk oor die doop in die Institusie nie. Dit is egter duidelik dat wat tot dusver oor die tweede deel gesê is (dit wil sê geloof en belydenis), nie anders verstaan kan word as teen die agtergrond van die inlywing in die kerk nie.

Die doop as inlywing in die kerk is die sigbare sy van die onsigbare, mistieke invoeging in die liggaam van Christus (Dankbaar 1941: 100). Hierdie inlywing geskied slegs wettig met diegene wat reeds tot die kerk behoort (Dankbaar 1941: 101). Calvyn wys in hierdie verband spesifiek ook na kinders van gelowiges. Hulle word nie gedoop asof hulle van dié oomblik af vir die eerste keer aan die kerk behoort nie, maar veeleer word hulle met die doop in die kerk ontvang, omdat hulle op grond van die belofte alreeds tot die gemeenskap van Christus behoort (O.S. V, 303: Inst. IV, 15, 22). Hierdie kerklike karakter bevestig hy verder deur die vereistes te stel dat die doop slegs in teenwoordig- 
heid van die gemeente (O.S. V, 300: Inst. IV, 15, 19) deur 'n wettig geroepe ampsdraer van die kerk bedien mag word (Dankbaar 1941: 101).

Die vereistes wat hy só stel, is gerig teen die wanopvattings van die RKK waar mense privaat gedoop is, of waar die nooddoop toegepas is. Daarenteen moet die hele kerk biddende getuie wees dat die dopeling vir God aangebied word onder die voorlesing van die geloofsbelydenis en die verhaling van die beloftes wat in die doop vervat is (O.S. V, 300: Inst. 15, 19).

Die kerklike karakter van die doop dui ook die verskil met die Wederdopers aan, aangesien dit feitelik die kinderdoop impliseer. Met verwysing na Calvyn se beskouing oor die belofte van God om tot die kerk te behoort wat oor die geslagte heenstrek, konkludeer Dankbaar:

"De grond voor de kinderdoop is daarmee gelegd en het diepgaand verschil tusschen de Reformatoren en de Wederdoopers wortelt derhalve in het kerkbegrip. Naarmate men den toegang tot de Kerk afhanklijk wil maken van het Verbond, dat God reeds vóór onze geboorte met ons sloot, óf van vrijwillige toetreding onzerzijds, zal men den kinderdoop of den Doop de volwassenen huldigen" (Dankbaar 1941: 101).

\section{DIE KINDERDOOP}

Calvyn behandel die kinderdoop in 'n aparte hoofstuk in sy Institusie sedert die uitgawe van 1539. Dit is sekerlik so dat groter kontak met Wederdopers tydens sy Straatburgse verblyf tot 'n mate hiervoor verantwoordelik was.

Vir sy bewysvoering ten gunste van die kinderdoop kon Calvyn hom nie beroep op kerklike tradisie nie, want dié is deur die hervormers verwerp (Wendel 1968: 286). Verder was dit juis die aanklag van die Wederdopers naamlik dat die kinderdoop 'n nuwigheid was wat deur die pousdom tot stand gebring is (Balke 1973: 219). Calvyn moes die leer oor die kinderdoop dus fundeer op die Bybel, trouens al was dit ook so, dat die leer van die kinderdoop noodwendig moes volg uit die reformatoriese opvatting van sonde, genade en kerk, sou Calvyn

"... haar toch nooit hebben kunnen of willen handhaven, als hij er niet een schriftuurlijke basis voor gevonden had" (Dankbaar 1941: 111).

Calvyn benader alle skriftuurlike gegewens met betrekking tot die kinderdoop per analogia fidei (Rom 12: 3-7) (O.S. V, 308: Inst. IV, 16, 4 “... qua omnem Scripturae interpretationem ad proportionem fidei exigere iubemmur. Rom 12a. 3, et b.6"). Dit maak dit vir hom moontlik 
om homself nie te beperk tot die vraag of die kinderdoop in die NT voorkom of nie, maar gee aan hom 'n baie wyer skriftuurlike basis. Terselfdertyd stel dit hom in staat om 'n Bybels-teologiese antwoord te gee op die biblisisme van die Wederdopers. In hierdie opsig is Calvyn se beskouing oor die gelykheid van die OT en die NT deurslaggewend.

Calvyn se uitgangspunt is sy beskouing oor die verhouding van signum en res sacramenti, waarmee hy aantoon dat 'n mens nie moet let op die uiterlike seremonie nie, maar op die belofte en die geestelike verborgenheid wat die Here met die uiterlike seremonie wil uitbeeld (O.S. V, 305: Inst. IV, 16, 2. Vgl ook Dankbaar 1941: 111).

Soos reeds aangetoon, interpreteer Calvyn die beloftes van die OT aan die vadere in ' $n$ soteriologiese sin. Christus is die fondament van die beloftes, dieselfde as in die NT Daarom moet die beloftes van die OT geestelik en eskatologies verstaan word. In verband met die kinderdoop wys Calvyn dadelik op die beloftes wat met die besnydenis gegee word. Calvyn stel dat besnydenis en doop 'n anagogiese verhouding met mekaar het. Met verwysing na Gen 19: 17, 10; Luk 20: 38; Matt 22: 23; Ef 2: 12 sê hy dat 'n geestelike belofte in die besnydenis aan die vadere gegee is, soos wat aan ons in die doop gegee word, aangesien die besnydenis vir hulle die vergewing van sondes en die afsterwing (mortificatio) van die vlees verteenwoordig. Verder stel hy, dat soos Christus die fondament van die doop is, in wie beide hierdie inhoude berus, is hy ook die fondament van die besnydenis. In hierdie verband verwys hy daarna dat Christus aan Abraham beloof is en in hom die seëning van alle volke (Gen 12: 3-2) (O.S. V, 306-307: Inst. IV, 16, 3). Die saak wat God met die besnydenis wil aandui, is dieselfde as die wat Hy met die doop wil aandui (Dankbaar 1941: 112), en soos wat die vergewing van sondes, die afsterwing van die vlees reeds daarin aangetoon word, so is dit ook waar van die keersy van hierdie inhoude, dit wil sê die eis tot lewensvernuwing, die besnydenis van die harte, dus die wedergeboorte. Uiteindelik is daarin die belofte van die regverdiging van die geloof en die ewige lewe gegee (Dankbaar 1941: 112).

Hoewel Calvyn by hierdie uiteensetting gebruik maak van die middeleeuse hermeneutiese term (anagoge), is sy benaderingswyse reformatories (scriptura sui ipsius interpres) (Hauck 1969: 73), deurdat hy na die locus classicus van die analogia fidei (Rom 12:3-7) verwys vir sy standpunt (O.S. V, 308: Inst. IV, 16, 4).

Calvyn stel dit soos volg:

"Die belofte, waarin, soos ons reeds uiteengesit het, die krag van die 
tekens geleë is, is in beide gelyk, naamlik die belofte van God se Vaderlike guns, van die vergewing van sonde en van die ewige lewe. Vervolgens is ook die afgebeelde saak dieselfde, naamlik die wedergeboorte. Die fondament, waarop die vervulling van die sake steun, is in albei één" (O.S. V, 308: Inst. IV, 16, 4. Skrywer se vertaling).

Calvyn stel vervolgens dat daar geen verskil in die innerlike misterie bestaan waarmee die krag en aard van die sakrament beoordeel moet word nie. Die uiterlike verskille is van minder belang, omdat die gewigtigste deel van die sakrament afhanklik is van die belofte en die betekende saak (Quum potissima pars a prommissione et re signata pendeat) (O.S. V, 308: Inst. IV, 16, 4). Hy konkludeer:

"'n Mens mag gevolglik vasstel, afgesien van die verskil in die sigbare seremonie, dat wat ook al tot die besnydenis behoort, tegelyk ook tot die doop behoort" (O.S. V, 308: Inst. IV, 16, 4. Skrywer se vertaling).

Die besnydenis was vir die Jode die teken van die inlywing in die kerk, waardeur hulle verseker is van hulle aanneming tot die volk van God. Net so word ons deur die doop vir God geheilig, om as sy volk gereken te word (O.S. V, 308: Inst. IV. 16, 4).

Met die besnydenis kom die verbond ter sprake. Calvyn wys daarop dat die besnydenis ' $n$ seël is om die belofte van die verbond te bevestig. Verder redeneer hy, dat as die verbond steeds bestaan, dat dit nie minder van toepassing kan wees op die kinders van Christene as op die van die volk van die OT nie. En as hulle deel het aan die saak, waarom sou die teken van hulle weerhou word? Calvyn wys vervolgens daarop dat die verbond met Abraham vandag nog vir Christene net so geld as destyds vir die Jode, want andersins sou dit beteken dat die koms van Christus die genade van God verminder en ingekort het insigself 'n lasterlike gedagte (O.S. V, 308-310: Inst. IV, 16, 5 en 6; Wendel 1968: 288; Dankbaar 1941: 113).

Calvyn onderskei tussen die kinders van gelowiges en die van ongelowiges wanneer hy uit 1 Kor 7: 14 aflei dat die kinders van gelowiges geheilig is in teenstelling met dié van afgodedienaars, selfs al is net een ouer 'n gelowige. Daarom behoort die teken van die verbond ook, soos in die OT vir kinders van die gelowiges bedien te word. Die doop het vir hierdie doel in die plek van die besnydenis gekom (O.S. 309-310: Inst. IV, 16, 6).

Hier moet egter opgemerk word dat Calvyn die verbond nie bloot as 'n genealogiese aangeleentheid beskou nie, trouens, dit sou sy hele beskouing van sonde en genade tot niet maak. In sy Hebreërkommentaar wys hy daarop dat die verbond oral daar geldig is, waar die 
koninkryk van Christus heerskappy voer (Torrance en Torrance 1963: 112). Hierdie interpretasie is in lyn met wat Calvyn as die vyfde verskil tussen die OT en die NT erken, naamlik dat Christus die verbondsgenade van God nie ingekort het nie, maar dit juis na alle nasies uitgebrei het deur die middelmuur van skeiding af te breek. Dit het nie die inhoud van die verbond verander nie, maar wel gesorg dat ook heidene in Abraham se nageslag ingeplant kon word (Milner 1970: 98; O.S. III, 433-434: Inst. II, 11, 11).

In die verlengstuk van hierdie argument word Dankbaar se beswaar afgewys, naamlik dat Calvyn nie daarin slaag om te sê waarom die doop in die plek van die besnydenis moes kom nie (Dankbaar 1941: 114). Die antwoord is vir Calvyn weer eens in Christus geleë, voor wie alle skaduagtige openbarings moes wyk (O.S. V, 283: Inst. IV, 14, 25; O.S. III, 401: Inst. II, 9, 3; O.S. III, 428: Inst. II, 11, 5). In hierdie opsig is sy retoriese vraag betekenisvol, wanneer hy vra, waarom God dan aan die Jode, wat maar ' $n$ onvolledige openbaring ontvang het, verlossing vir hulle kinders sou beloof, maar nie aan die Christene wat die volledige openbaring in Christus ontvang het nie (Balke 1973: 221-222). Dieselfde geld in omgekeerde sin wanneer Calvyn vra hoe Abraham die vader van alle gelowiges genoem kan word, maar vir homself is daar nie plek tussen hulle nie? (O.S. III, 411: Inst. II, 10, 11). Calvyn verwys na Matteus 13: 15 waar Christus die kinders na Hom toe laat kom het om aan te dui dat Christus nie die genade van die Vader ingekort het nie, maar juis uitgebrei het. As Christus van sulkes gesê het dat hulle die saak deelagtig was, naamlik die koninkryk van die hemele, waarom sal aan hulle die teken geweier moet word wat hulle toelating tot die ryk aandui? (O.S. V, 310-311: Inst. IV, 16, 7; Pont sa: 11). Net so verwys hy na die swye van die sg oikos-tekste oor die feit dat kinders gedoop is. Daaruit mag nie biblisisties afgelei word dat geen kinders gedoop is nie. Hy wys daarop dat indien dit die geval sou wees, vrouens byvoorbeeld nie aan die nagmaal sou moes deelneem nie, omdat nêrens eksplisiet na hulle deelname verwys word nie (O.S. V, 311-312: Inst. IV, 16, 8; Dankbaar 1941: 115).

Calvyn wil dus kennelik met die verwysing na Matteus 13: 15 en die oikos-tekste nie soseer die kinderdoop bewys nie, maar hy wil eerder die verband aantoon waarbinne God met sy uitverkorenes werk. As dit dan só is, sou dit dwaas wees om die teken van die aanneming tot kinders van God aan kinders te weier.

Die argument wat Calvyn vervolgens gebruik om die Wederdopers asook Servet te weerlê, kom reeds voor en hoef nie herhaal te word nie. 
Die volgende saak wat na vore kom, is die kwessie van kindergeloof. Dit gaan om die sola fide van die Hervorming en die Wederdopers het daarop gewys dat ' $n$ kind nie tot geloof in staat is nie. Sulke kinders kan nie wedergebore word nie. Calvyn gee toe dat onherbore vlees en bloed die hemelryk nie sal beërwe nie, maar hy aanvaar nie dat kinders sonder meer nie verlos sal word nie. As hy na Johannes se heiliging vanaf die moederskoot verwys, sê hy eksplisiet dat hy dit nie voorhou as 'n voorbeeld nie, maar bloot om daarmee aan te toon, dat God nie deur mense in sy genade beperk mag word, deurdat hulle sê dat Hy nie in staat sou wees om kinders, sonder geloof, te red nie (O.S. V, 320-321: Inst. IV. 16, 17).

Met die argument dat Christus self 'n kind was wat van die Heilige Gees ontvang is, wil Calvyn daarop wys dat kindheid per se geen hindernis kan wees vir die heiliging deur God nie. Dit kom dus weer eens nie aan op die subjektiewe kwaliteite van die gelowige nie, maar op die soewereine genade van God (O.S. V, 321-323: Inst. IV, 16, 18).

Verskeie skrywers het die kwessie van kindergeloof by Calvyn van alle kante beredeneer (Dankbaar 1941: 120-122); Wendel 1968: 289; Torrance 1960: 125-126). Dit is egter nie nodig om verder daarop in te gaan nie, want dit was vir Calvyn se uitgangspunte nie werklik ter sake nie. Wat hy slegs met sy redenasies oor die saak wou bereik, is om aan te toon dat God se genade nie daardeur beperk kan word of ' $n$ kind nou wel glo, berou kan hê, gedoop is of ook vroeg gesterf het nie. Wat waarskynlik is, is dat hierdie skrywers nie genoeg aandag daaraan gegee het nie, dat die kwessie van die verlossing van kinders gesien moet word teen die agtergrond van die uitverkiesingsleer. Dit word gesê dat Calvyn in aansluiting by Augustinus en Luther in 1536 die kindergeloof geleer het, maar dat hy algaande daarvan wegbeweeg het (Wendel 1968: 286-287; Dankbaar 1941: 120-122). Dit moet egter opgemerk word dat in die 1536-uitgawe van sy Institusie, waarin Wendel bv meen om sy leer van die kindergeloof te bewys, Calvyn reeds die geloof teen die agtergrond van die uitverkiesing stel - of dit dan nou op 'n vroeë of latere ouderdom tot ' $n$ mens kom, is nie ter sake nie (O.S. I, $-36)$.

Hiervandaan is daar niks wat kan verhinder dat Calvyn sal leer nie dat ' $n$ kind binne die verbond gedoop behoort te word, met die oog op sy toekomstige geloof, al wys hy ook op die geheime werking van die Heilige Gees (O.S. V, 324: Inst. IV, 16, 20).

Die verhouding tussen doop en uitverkiesing is egter nie omkeerbaar nie, sodat 'n mens sou moet besluit dat 'n ongedoopte nie uitver- 
kies en daarom verlore is nie (Dankbaar 1941: 126). Calvyn stel dit baie duidelik dat die doop nie heilsnoodsaaklik is nie, alhoewel dit nie geminag mag word nie en onder normale omstandighede bedien moet word. Minagting sou God se verbond geweld aandoen (O.S. V, 311: Inst. IV, 16, 26). Calvyn sluit af deur op die troos te wys wat daar vir ouers spruit uit die doop van hulle kinders; die sekere wete bevestig deur Woord en sigbare teken dat God vir hulle kinders sal sorg, selfs lank na die dood. Dit behoort as ' $n$ aansporing tot dankbaarheid teenoor God en gevolglik onderwysing van die kinders in die vrese van die Heer te dien (O.S. V, 340-341: Inst. IV, 16, 32).

\section{SLOTOPMERKINGS}

Calvyn se doopleer moet grotendeels beskou word teen die agtergrond van sy leer van die uitverkiesing, van die verbond (gelykheid van OT en NT), en van die sakramente. Wie lees wat hy oor die doop sê, kom nie daarvan weg dat dit sake is wat deurentyd aanwesig is nie. Maar in dieselfde mate is sy leer van sonde, genade en van die kerk teenwoordig. 'n Mens sou verder kon gaan en ontdek dat dit wat hy sê oor die Vader nie losstaan van die doop nie en ook nie wat hy van die Heilige Gees sê nie. Uiteindelik moet 'n mens besluit dat daar by Calvyn geen geslote teologiese sisteem bestaan het nie. Daar is maar net ' $n$ middelpunt Jesus Christus. Die rede hiervoor is die groot respek en persoonlike vroomheid waarmee hy die waarheid van die Woord van God benader het. Sy logiese redeneervermoë, sy sistematiese talente het 'n halt geroep voor die waarheid van die Woord. Wanneer die waarheid irrasioneel blyk moet die ratio homself beteuel (Balke 1973: 221). Daarom sal daar teenstrydighede in al sy leerstukke gevind word, so ook in die doopleer. sê:

Dit is goed om in hierdie opsig weer na Calvyn self te luister as hy

"Dit sal die beste reël vir ingetoënheid wees: Volg God nie alleen as leidsman terwyl ons leer nie, maar as $\mathrm{Hy}$ ophou om te onderrig, moet ons ook ophou om wys te wees" (O.S. IV, 372: Inst. III, 21, 3).

Deurdat hy egter soveel as moontlik probeer het om die waarheid van die hele Bybel oor die doop na vore te bring, het hy daarin geslaag dat die Wederdoperdom minstens in sy leeftyd nie meer in Genève kop uitgesteek het nie (Dankbaar 1941: 111).

In die hedendaagse diskussie rondom doop en herdoop sal dit goed wees om weer na Calvyn te luister en te probeer verstaan wat hy sê, 
want dit blyk dat die ou kwessie van die Pelagianisme, die SemiPelagianisme en Arminianisme steeds die wortel van die kwaad is. Op voetspoor van Calvyn waarsku Balke in ons tyd:

"De Doop is niet het antwoord van de bekeerde mens op de roeping van God. Het is net teken van Gods verbond. God handelt in de Doop, niet de mens. Wie de kinderdoop verwerpt, maakt Jezus los van het Oude Testament, brengt een ongeoorloofde scheiding aan tussen de gemeente van Christus en het volk van het Oude Verbond en opent, door de eenheid van de Schrift prijs te geven, de deur voor geestdrijverij" (Balke 1973: 224).

'n Positiewe antwoord op die vrae van ons dag sou wees, as ons groter erns sou maak met wat Calvyn as die tweede doel aandui waartoe God vir ons die doop ingestel het, naamlik om tot 'n belydenis by die mense te dien. Dit is die taak van die hele kerk, maar kan in die besonder deur die diens van prediking en kategese volvoer word.

Die verwaarlosing van die belydeniskarakter van die doop, veral in retrospeksie by die katkisant en lidmaat, verduister die sekerheid van die heil vir die gelowige. Die hybris van die mens gryp hierdie geleentheid aan om gehoor te gee aan die valse leerstelling van die hedendaagse Wederdoperdom wat die kinderdoop beskryf as besnydenisdoop, en die grootdoop as belydenisdoop. Op voetspoor van Calvyn moet die kerk by sulke spitsvondigheid verbygaan en daarop wys dat daar maar éên doop is, die doop van die verbond wat in die plek van die besnydenis gekom het om ons te verseker van ons ewige saligheid in Jesus Christus. Ons kan die volle inhoud hiervan na vore laat kom, deur lewenslank te bely dat die doop die teken is waarmee God ons verseker dat ons lank voor die grondlegging van die wêreld reeds aan Hom behoort.

Literatuurverwysings

BALKE, W 1973. Calvijn en de doperse radikalen. Amsterdam: Tom Bolland.

BARTH, P, G Niesel 1926-1974. Joannis Calvini opera selecta, 5 Bde. München: Kaiser.

MCNEILL, JT (ed) 1960. Calvin: Institutes of the Christian Religion, 2 vols, Philadelphia: Westminster.

BAKER, JW 1980. Heinrich Bullinger and the Covenant. Athens Ohio: Ohio University.

WENDEL, F 1968. Calvin. Neukirchen-Vluyn: Neukirchener.

NIESEL, W 1957: Die Theologie Calvins. 2. Auflage. München: Kaiser.

TORRANCE, TF 1960. Calvins Lehre von der Taufe, in J Moltmann (Hrsg). Calvin-Studien 1959. Neukirchen: Neukirchener.

DANKBAAR, WF 1941. De sacramentsleer van Calvijn. Amsterdam.

HAUCK, F 1969. Theologisches Fack-und Fremdwörterbuch. 5. Auflage. München: Siebenstern Taschenbuch.

TORRANCE, DW \& TF Torrance 1963. The Epistle of Paul The Apostle to the Hebrews in die reeks Calvins Commentaries. Grand Rapids: Wm B. Eerdmans.

MILNER, BC 1970. Calvin's Doctrine of the Church. Leiden: Brill. 